\title{
ANALISIS STRUKTURAL, NILAI MORAL DAN NILAI SOSIAL DALAM NOVEL GURU AINI KARYA ANDREA HIRATA
}

\author{
Sekar Ayutya IAI Darussalam Blokagung Banyuwangi
}

sekarayutya200@gmail.com

\begin{abstract}
Abstrak
Novel merupakan sebuah karya sastra yang dibangun secara totalitas melalui berbagai unsur instrinsik dan ekstrinsik yang saling berkaitan serta bersifat artistik. Berdasarkan hal tersebut, peneliti tertarik untuk mengkaji unsurunsur struktural pembangun karya sastra, nilai moral dan nilai sosial yang terkandung dalam sebuah novel dengan judul Guru Aini karya Andrea Hirata. Jenis pendekatan yang digunakan dalam penelitian ini adalah pendekatan kualitatif dengan metode deskriptif. Penelitian ini adalah penelitian pustaka dengan menggunakan sumber data berupa dokumen tertulis hasil kesusastraan sebuah novel berjudul Guru Aini karya Andrea Hirata. Hasil dalam penelitian ini adalah sebagai berikut; (1) Tema mengenai pendidikan dan perjuangan dalam meraih sebuah impian. (2) Alur yang digunakan yaitu alur maju dan mundur. (3) Terdapat dua jenis tokoh dalam novel ini. Sebagai tokoh utama yaitu Guru Desi dan Aini. Sedangkan sebagai tokoh tambahan yaitu Debut Awaludin, Pak Tabah, dan Laili. (4) Latar yang digunakan berupa latar tempat, latar waktu, dan latar sosial. (5) Sudut pandang yang digunakan adalah sudut pandang persona ketiga dengan teknik "dia" mahatahu. (6) Amanat yang terkandung berupa idealisme seorang guru, sikap pantang menyerah, dan berbakti kepada kedua orang tua. Adapun nilai moral yang terkandung dalam novel Guru Aini karya Andrea Hirata meliputi, nilai hubungan manusia dengan Tuhan, hubungan manusia dengan diri sendiri, hubungan manusia dengan sesama, dan hubungan manusia dengan lingkungan. Sedangkan nilai sosial yang terkandung meliputi nilai kasih sayang, tanggung jawab, dan keserasian hidup.
\end{abstract}

\section{Abstract \\ Kata Kunci:Pendekatan Struktural, Nilai Moral, Nilai Sosial}

Novel is a literary work that is built in totality through various intrinsic and extrinsic elements that are interrelated and have an artistic character. Based on this, the researcher is interested in studying the structural elements that build literary works, moral values and social values contained in a novel entitled Guru Aini by Andrea Hirata. The type of approach used in this research is a qualitative approach with descriptive methods. This research is a library research using data sources in the form of written documents from a novel entitled Guru Aini by Andrea 
Hirata. The results in this study are as follows; (1) The theme of education and the struggle to achieve a dream. (2) The flow used is the forward and backward flow.

(3) There are two types of characters in this novel. As the main characters, namely Guru Desi and Aini. Meanwhile, as additional figures, namely Debut Awaludin, Pak Tabah, and Laili. (4) The setting used is in the form of place setting, time setting, and social setting. (5) The point of view used is the point of view of the third person with the omniscient "he" technique. (6) The mandate contained in the idealism of a teacher, an unyielding attitude, and devotion to both parents. The moral values contained in the novel Guru Aini by Andrea Hirata include the value of human relations with God, human relations with oneself, human relations with others, and human relations with the environment. While the social values contained include the values of love, responsibility, and life harmony.

Keywords: Structural Approach, Moral Value, Social Value

\section{A. Pendahuluan}

Karya sastra merupakan sebuah hasil keatifitas yang lahir dari imajinasi seorang pengarang dengan perpaduan bahasa yang indah sebagai perantaranya. Karya sastra juga disebut sebagai luapan emosi pengarang yang dituangkan kedalam sebuah tulisan agar dapat dinikmati oleh pembacanya. Oleh sebab itu, selain imajinasi dan bahasa, faktor psikis dan sosial yang dialami seorang pengarang juga berperan penting dalam pembentukan sebuah karya sastra.

Dalam kajiannya, karya sastra merupakan hasil kreasi manusia yang dilahirkan dari pemikiran serta imajinasi dan dituangkan melalui sebuah bentuk baik secara lisan maupun tulisan. Seorang pengarang diibaratkan sebagai Tuhan dalam kehidupan. Pengarang akan menciptakan, menentukan dan menguasai segala hal yang ada dalam karya sastra, sehingga penciptaan karya sastra tersebut merupakan hak penuh pengarang.

Salah satu hasil dari karya sastra yang berbentuk prosa fiksi adalah novel. Dalam sebuah novel akan disajikan cerita fiksi atau tidak nyata lengkap dengan unsur-unsur pembangunnya. Pengarang akan menggambarkan model kehidupan sesuai dengan kehendak yang diinginkan. Cerita dalam novel, sering dianggap sebagai sebuah pesan kehidupan yang dapat membuat manusia lebih arif, bijaksana dan berbudaya, sehingga dapat disebut sebagai karya yang "memanusiakan manusia" (Nurgiyantoro, 2010: 4). 
Hal tersebut merupakan sebuah upaya pengarang untuk memberi amanat kepada para pembaca agar menjadi seseorang yang berbudaya dan berakal budi serta saling menghormati, yang mana pesan tersebut disampaikan melalui tulisan yang dikemas dalam sebuah alur yang ada dalam karya sastra tersebut.

Novel merupakan sebuah karya sastra yang dibangun secara totalitas melalui berbagai unsur instrinsik dan ekstrinsik yang saling berhubungan erat serta bersifat artistik. Novel dikatakan sebagai sebuah totalitas dari berbagai unsur pembangun yang merupakan salah satu subsistem organisme (Nurgiyantoro, 2010: 22). Unsur instrinsik bersumber pada isi teks atau cerita dalam sastra tersebut, sedangkan unsur ekstrinsik bersumber dari luar karya sastra tersebut. Kedua unsur tersebut jika dikemas secara runtut dan berkala akan membangun cerita dalam sebuah novel secara totalitas, sehingga para pembaca akan larut dalam alur yang disajikan.

Dalam sebuah novel terkandung gambaran tentang nilai-nilai kehidupan masyarakat yang banyak memberikan manfaat bagi pembaca. Sehingga novel tidak hanya dijadikan sebagai hiburan semata, namun juga dapat dijadikan sebagai media pembelajaran yang mengandung pesan-pesan moral. Karenanya, seorang penulis yang berhasil adalah dia yang dapat membawa pembaca menyelami dunia imajinasi melalui apa yang ditulis entah itu mengenai percintaan, pendidikan, semangat hidup, kesedihan, perjuangan, kebahagiaan maupun keberhasilan. Untuk dapat menyimpulkan nilai yang terkandung dalam sebuah novel, pembaca harus memahami struktur serta unsur-unsur pembangun karya sastra.

Adapun unsur-unsur tersebut mengacu pada unsur instrinsik dan ekstrinsik dalam sebuah karya sastra yang meliputi tema, alur, penokohan, latar, sudut pandang dan juga amanat berupa nilai-nilai kehidupan yang terkandung dalam sebuah karya sastra tersebut yakni berupa nilai moral, sosial, dan juga nilai pendidikan.

Cerita dalam sebuah novel lebih mengacu pada realitas yang lebih tinggi dan psikologi yang mendalam atau kejadian apa saja yang telah terjadi ataupun dialami seseorang. Oleh karena itu, cerita yang diangkat dalam sebuah novel adalah peristiwa yang terjadi dalam kehidupan masyarakat baik berupa konflik fisik maupun batin. 
Novel yang akan dikaji dalam penelitian ini adalah novel ke-12 karya Andrea Hirata dengan judul Guru Aini. Novel Guru Aini merupakan sebuah novel yang menggambarkan tentang perjuangan dan idealisme seorang guru matematika yang ditugaskan disebuah daerah pelosok ujung Pulau Sumatera yakni Tanjong Hampar serta pertemuannya dengan seorang murid yang tak bersahabat dengan matematika namun mempunyai tekad kuat dalam menggapai impiannya.

Tujuan dalam penelitian ini adalah untuk mengetahui unsur struktural, nilai moral dan nilai sosial yang terkandung dalam Novel Guru Aini karya Andrea Hirata.

\section{B. Landasan Teori 1. Pengertian Novel}

Istilah novel berasal dari bahasa latin novellas/ novies yang bermakna baru, kemudian diadaptasi kedalam bahasa Inggris menjadi istilah novel. Menurut Abrams (dalam Hafid, 2019: 19), novel merupakan sebuah karya sastra fiksi yang berbentuk narasi dengan menceritakan berbagai peristiwa yang terjadi dalam kehidupan. Sedangkan menurut Nurgiyantoro (2010: 9) menjelaskan bahwa istilah novella dan novelle mengandung makna yang sama dalam istilah bahasa Indonesia yakni novellet (Inggris: novellet), yang berarti sebuah karya sastra berbentuk prosa fiksi atau khayalan semata dengan tidak terlalu panjang dan juga tidak terlalu pendek.

Pujiharto (2012: 8) menjelaskan bahwa "Novel merupakan sebuah gambaran mengenai kehidupan dan perilaku yang nyata pada zaman novel itu ditulis". Novel dikatakan sebagai sebuah prosa fiksi yang mengandung unsur-unsur tertentu mengenai permasalahan dalam kehidupan yang disajikan secara kompleks.

Karya fiksi memang mempunyai arti sebagai sesuatu yang tidak nyata, namun karya sastra bukanlah sebuah kebohongan karena mengandung makna fiksi. Fiksi yang dimaksudkan dalam sebuah karya sastra ini, lebih menekankan kepada kekuatan kesastraan daya penceritaannya. Sehingga menjadikan karya sastra tidak hanya 
sebagai khayalan semata, namun juga sebagai cerminan dari hal yang dirasakan, dilihat serta dialami oleh pengarang (Hafid \& Eko, 2017: $6)$.

\section{Jenis-Jenis Novel}

Seiring dengan perkembangan zaman diera globalisasi, membawa dampak yang begitu besar dalam dunia pendidikan terutama dalam ranah kesusastraan. Hal ini dibuktikan dengan adanya perkembangan dalam khasanah karya sastra di Indonesia yakni klasifikasi jenis novel dari segi karakteristiknya. Nurgiyantoro (2018: 20-29) membedakan jenis novel kedalam kelompok kelompok.

Adapun pembagian adalah sebagai berikut;

1). Novel populer

Novel populer merupakan sebuah novel yang hanya populer pada masanya serta banyak penggemarnya khususnya pembaca di kalangan remaja (Nurgiyantoro, 2018: 22). Novel populer tidak menampilkan permasalahan kehidupan secara intens, tidak meresapi hakikat kehidupan sehingga bersifat artifisial dan sementara serta cepat ketinggalan zaman. Permasalahan yang diangkat dalam novel populer merupakan permasalahan ringan tetapi aktual dan menarik namun hanya sampai pada tingkat permukaan zaman tersebut.

Sastra yang digunakan dalam novel populer digunakan sebagai perekam kehidupan sesaat dan tidak banyak membicarakan kehidupan dalam berbagai kemungkinan. Menurut Kayam, 1981: 88 (dalam Nurgiyantoro, 2018: 22) menjelaskan bahwa dalam novel populer permasalahan yang disajikan merupakan rekaman-rekaman kehidupan dengan tujuan para pembaca akan mengenali kembali pengalaman yang mereka alami sehingga para pembaca seolah menceritakan 
pengalaman hidupnya sendiri atau sebagai identifikasi terhadap diri sendiri.

2). Novel serius

Berbeda dengan novel populer, novel serius berusaha mengajak para pembaca untuk meresapi hakikat kehidupan melalui pesan moral yang disampaikan pengarang dalam tulisannya. Sehingga novel serius tidak hanya bertujuan sebagai hiburan semata, namun juga sebagai sarana edukasi tentang nilai-nilai kehidupan yang disajikan dalam novel tersebut. Novel serius dapat bertahan lama dan tidak pernah ketinggalan zaman karena selalu mengangkat hakikat kehidupan yang akan bertahan sepanjang masa. Oleh karena itu, novel serius juga dipandang sebagai sastra yang bernilai tinggi.

3). Novel teenlit

Novel teenlit merupakan novel yang sangat digandrungi oleh kaum remaja putri yang haus akan bacaan sesuai dengan kondisi kejiwaannya. Dalam novel ini, mengangkat sebuah cerita mengenai aktualisasi dan representasi eksistensi diri sebagai seorang remaja dengan penggambaran yang mencerminkan diri, dunia, cita-cita, gaya hidup, gaya gaul, dan lain-lain yang menyangkut permasalahan remaja. Sehingga tidak salah jika novel ini sangat digemari remaja sebagai salah satu media hiburan.

\section{Unsur-unsur kajian}

Analisis struktural karya sastra dapat dilakukan dengan mengidentifikasi, mengkaji, dan mendeskripsikan fungsi dan hubungan antar unsur yang bersangkutan. Dalam kajian struktural meliputi kajian yang mengenai unsur-unsur pembangun karya sastra atau unsur instrinsik yang meliputi tema, alur,tokoh dan penokohan,latar, sudut pandang dan amanat (Sumaryanto, 2019: 4). 
Dalam ruang lingkup karya sastra, unsur-unsur pembangun struktural terdiri dari tema, fakta cerita dan sarana sastra. Adapun fakta cerita terdiri atas alur, tokoh, dan latar. Sedangkan sarana sastra terdiri atas sudut pandang, gaya bahasa dan suasana, simbol-simbol imajinasi dan cara pemilihan judul.

Kajian struktural meliputi kajian mengenai unsur-unsur yang berhubungan dengan pembangun karya sastra tersebut. Adapun unsur pembangun tersebut meliputi unsur instrinsik yang terdapat dalam sebuah novel. Unsur instrinsik yang dikaji dalam sebuah novel meliputi tema, alur, penokohan, latar, dan sudut pandang. Secara lebih rinci, berikut dipaparkan unsur-unsur instrinsik novel:

1). Tema

Tema merupakan sebuah gagasan dasar cerita yang menopang sebuah karya sastra sebagai struktur semantik dan bersifat abstrak dan dimunculkan melalui motif secara implisit (Nurgiyantoro, 2018: 116). Tema dapat diartikan sebagai sebuah cerita yang secara khusus menerangkan sebagian besar unsur cerita melalui cara yang sederhana. Sehingga tema dapat dipandang sebagai dasar cerita, gagasan dasar umum sebuah karya sastra fiksi berupa novel.

Senada dengan pendapat tersebut, Sumaryanto (2019: 4-5) menjelaskan bahwa tema merupakan dasar sebuah cerita yang pada hakikatnya merupakan permasalahan yang menjadi titik tolak pengarang dalam menyusun cerita. Melalui tema, pengarang akan mengembangkan gagasan atau ide kedalam sebuah cerita.

2). Alur (Plot)

Alur atau plot merupakan struktur rangkaian kejadian atau peristiwa dalam sebuah cerita yang disusun sebagai relasi fungsional dalam bagian-bagian karya sastra fiksi. Secara umum alur merupakan rangkaian peristiwa dalam sebuah cerita yang bersifat kausal. Menurut Stanton, 2012: 26 (dalam skripsi Dewi Zhafarina : 2018) menjelaskan bahwa peristiwa kausal merupakan peristiwa 
yang berdampak pada peristiwa lain dan tidak dapat diabaikan karena berpengaruh pada keseluruhan karya.

Menurut Sumaryanto (2019: 5) alur merupakan jalan cerita yang terjalin secara berurutan dengan memerhatikan sebab akibat yang akan terjadi sehingga menjadikannya sebuah kesatuan yang padu, bulat, dan utuh. Dengan demikian dapat disimpulkan bahwa, alur merupakan sebuah jalan cerita yang terjadi secara beruntun dan padu dengan menjadikan sebab akikat dalam ceritanya.

\section{3). Tokoh dan Penokohan}

Tokoh dalam sebuah cerita merupakan para pelaku yang diciptakan oleh pengarang mempunyai karakter dan sifat sesuai dengan yang diinginkan untuk mendukung jalannya sebuah cerita. Sedangkan penokohan sendiri lebih mengarah pada perwatakan seorang tokoh. Penokohan merupakan cara pengarang menampilkan tokoh-tokoh dan watak-wataknya dalam sebuah cerita. Karakter tokoh dapat diketahui melalui sikap tokoh dalam menanggapi suatu kejadian atau peristiwa yang ada. Dalam sebuah karya sastra, tokoh dan penokohan merupakan unsur penting dalam sebuah cerita. Berdasarkan perannya, Waluyo (dalam Hafid, 2019: 26) membedakan penokohan kedalam tiga jenis yaitu protagonis, antagonis dan tritagonis.

Nurgiyantoro (2013:176-177) membedakan tokoh melalui tingkat penting dan peranan seorang tokoh menjadi dua bagian, yakni tokoh utama dan tokoh tambahan.

4). Latar

Latar merupakan lingkungan tempat terjadinya suatu peristiwa dengan keadaan yang berlangsung. Latar berisi tentang keterangan waktu, ruang, dan suasana yang terjadi dalam suatu karya sastra (Sudjiman, 1988: 44 dalam Skripsi Dewi Zhafarina : 2018 ).

Pada hakikatnya, latar menyajikan kepada pembaca sebuah dunia yang lengkap dengan penghuni serta permasalahannya. Latar 
dapat dipergunakan untuk beberapa maksud dan tujuan. Latar biasanya dilukiskan dengan terang dan jelas agar mudah diingat serta memperbesar keyakinan terhadap tokoh, gerak, dan tindakannya. Latar sangat berkaitan dengan elemen-elemen yang memberikan kesan abstrak terhadap lingkungan, baik mengenai waktu maupun tempat dimana tokoh menjalankan perannya. Nurgiyantoro (2010: 227) membedakan latar menjadi tiga kategori yaknilatar tempat, latar waktu, latar sosial

5). Sudut pandang

Sudut pandang (point of view) merupakan sebuah cara dikisahkannnya cerita oleh pengarang sebagai sarana dalam penyajian kafya sastra fiksi. Menurut Nurgiyantoro (2013: 338) menjelaskan bahwa sudut pandang pada hakikatnya merupakan sebuah strategi, teknik, serta siasat yang sengaja dipilih oleh pengarang dalam mengemukakan gagasan cerita.

Sudut pandang akan memengaruhi dampak dari sebuah cerita, sehingga sudut pandang merupakan salah satu unsur pembangun cerita yang digunakan oleh pengarang dalam memosisikan diri. Dalam kajiannya, Nurgiyantoro mengelompokkan sudut pandang kedalam beberapa bagian, yaitu: a). Sudut pandang persona ketiga:

"Dia". b). Sudut pandang persona pertama: "Aku"

6). Amanat

Sebuah karya sastra selain berfungsi sebagai hiburan juga berfungsi sebagai sarana education atau pendidikan. Dengan kata lain, pengarang akan menghibur para pembaca serta memberikan pesan-pesan kehidupan dalam karya sastranya.

Amanat merupakan unsur isi dalam karya sastra yang mengarah pada nilai-nilai, sikap, perilaku, serta sopan santun dalam pergaulan yang dihadirkan pengarang melalui tokoh-tokoh yang ada dalam sebuah cerita (Kenny, 1966:86 via Nurgiyantoro dalam Skripsi Erizka Febriana, 2018). Berdasarkan pengertian tersebut 
amanat merupakan sebuah pesan yang disampaikan oleh pengarang kepada pembaca melalui karya sastra yang diciptakan baik secara langsung maupun tidak langsung.

\section{Hakikat Nilai Moral}

Dalam Kamus Besar Bahasa Indonesia edisi kelima, nilai mempunyai makna 1). harga (dalam arti tafsiran harga), 2). harga uang (dibandingkan dengan harga uang yang lain), 2). angka kepandaian; biji; ponten (rata-rata) 4). banyak sedikitnya isi; kadar; mutu; 5). sifat-sifat (halhal) yang terpenting atau berguna bagi manusia 6). sesuatu yang menyempurnakan manusia sesuai dengan hakikatnya sebagai hal yang berguna bagi manusia serta dapat menyempurnakan manusia sesuai dengan hakikatnya. Nilai dijadikan sebagai landasan, alasan serta motivasi dalam bersikap dan bertingkah laku, baik secara disadari maupun tidak.

Moral merupakan sebuah ajaran mengenai baik buruknya suatu perkara mengenai perbuatan, sikap, kewajiban, dan sebagainya. Moral dapat kita temukan dalam aspek kehidupan. Oleh sebab itu, banyak karya sastra yang menyelipkan berbagai pesan moral dalam kisahnya. Moral dalam sebuah karya sastra merupakan sesuatu yang ingin disampaikan oleh pengarang kepada para pembaca melalui makna yang terkandung dalam cerita tersebut.

Moral dalam karya sastra biasanya mencerminkan pandangan hidup seorang pengarang terhadap nilai-nilai kehidupan yang disampaikan kepada pembaca melalui tulisannya yang mengandung makna tertentu. Nilai moral tersebut biasanya ditujukan kepada pembaca agar mengikuti saran pengarang untuk memberikan sebuah tanggapan dan mengikuti pandangan pengarang (Nurgiyantoro, 2010: 321).

Nilai moral merupakan sebuah nilai yang tinggi berupa ukuran untuk mengatur tingkah laku dan perbuatan manusia yang dianggap baik maupun buruk dengan mencakup seluruh persoalan kehidupan. Secara garis besar, persoalan kehidupan manusia dibedakan kedalam tiga hal 
yakni menurut Nurgiyantoro ( dalam Skripsi Aluisius Titus Kurniadi, 2019).

1) Nilai Moral dalam Hubungan Manusia dengan Tuhan

2) Nilai moral dalam hubungan manusia dengan diri sendiri

3) Nilai moral dalam hubungan manusia dengan sesama

4) Nilai moral dalam hubungan manusia dengan lingkungan

\section{Hakikat Nilai Sosial}

Dalam kehidupan bermasyarakat, nilai mempunyai makna sebagai kumpulan sikap dan perasaan yang diwujudkan melalui perilaku atau tindakan sosial seseorang. Nilai sosial dijadikan sebagai tolok ukur dan penilaian terhadap pantas tidaknya suatu sikap atau tindakan dalam kehidupan bermasyarakat. Nilai sosial merupakan nilai yang dianut oleh suatu masyarakat mengenai apa yang dianggap baik dan buruk oleh kalangan masyarakat. Nilai sosial memberikan petunjuk umum terhadap tingkah laku dalam kehidupan sehari-hari. Nilai sosial dianggap sebagai dasar mempertimbangkan keputusan seseorang melalui perilaku masyarakat yang ada dalam lingkungan tersebut.

Pada hakikatnya, nilai mengarah pada perilaku dan pertimbangan seseorang, tetapi tidak menghakimi apakah sebuah perilaku itu benar ataupun salah. Adapun nilai-nilai yang menyangkut tentang nilai sosial adalah nilai yang berhubungan dengan perilaku dengan menggambarkan suatu tindakan, tingkah laku, atau kebiasaan dalam masyarakat serta nilai sikap yang secara umum menggambarkan kepribadian suatu masyarakat dalam lingkungan tersebut (Alfin, 2010 dalam Jurnal Susianti Aishah, 2015).

\section{B. Metode Penelitian}

Penelitian ini menggunakan pendekatan kualitatif dengan metode deskriptif. Prosedur penelitian kualitatif menghasilkan data yang berbentuk deskripsi dengan menggunakan data tertulis atau lisan dari orang atau objek yang diamati (Moleong, 2013: 4). Analisis secara kualitatif difokuskan pada penunjukan makna, penelitian, 
penjernihan dan penempatan data pada konteksnya untuk menghasilkan sebuah data deskripsi berupa kata-kata tertulis atau lisan dari apa yang telah diamati. Sedangkan metode deskriptif merupakan suatu metode yang digunakan untuk menganalisa sebuah data atau gambaran secara sistematis, faktual serta akurat mengenai fenomena yang diselidiki. Data yang diperoleh berupa gambaran atau kata-kata yang kemudian dianalisa dengan mengaitkan data yang ada berdasarkan landasan teori para ahli sehingga menghasilkan deskripsi berupa kata dan bukan angka.

Dalam penelitian ini, dilakukan analisa terhadap objek kajian yang menjadi sumber data yakni novel berjudul Guru Aini karya Andrea Hirata. Penulis mencatat data-data yang berhubungan dengan unsur-unsur pembangun serta nilai-nilai yang terkandung di dalam novel tersebut dan menyimpulkannya ke dalam sebuah deskripsi.

\section{Hasil dan Pembahasan}

Berdasarkan hasil penelitian yang telah dilakukan menunjukan bahwa dalam novel Guru Aini karya Andrea Hirata mengandung unsur-unsur pembangun cerita sebagai berikut :

1. Tema

Dalam sebuah karya sastra, tema merupakan dasar dari pengembangan sebuah cerita dimana tema tersebut menjadi penopang yang menjadikan struktur semantik yang bersifat abstrak serta dimunculkan melalui motif secara implisit (Nurgiyantoro, 2018; 116).

Tema disebut sebagai dasar sebuah cerita yang pada hakikatnya merupakan titik tolak dari sebuah alur cerita. Dalam novel Guru Aini karya Andrea Hirata, peneliti menemukan dua tema yang kandung didalamnya. Adapun tema tersebut terdapat pada kutipan sebagai berikut :

a. Tema Mayor

Tema mayor merupakan tema utama dalam sebuah karya sastra. Novel Guru Aini menunjukkan tema mengenai pendidikan dan idealisme seorang guru. Adapun tema tersebut terdapat pada kutipan sebagai berikut : 
"Sejak berjumpa dengan Bu Marlis, kelas 3 SD dulu, aku sudah ingin menjadi guru matematika, Bu. Itulah harapan terbesar dalam hatiku, karena aku selalu merasa, menjadi guru matematika adalah alasan mengapa di dunia ini, aku, Desi Istiqomah, ada." (Guru Aini, hal. 1)

Dalam kutipan menjelaskan bahwa tokoh Desi Istiqomah mempunyai citacita sebagi guru matematika karena kecintaannya kepada seorang guru SD yang telah mengajarkannya tentang banyak hal terutama idealisme seorang guru dalam mengabdikan ilmunya. Guru merupakan sosok pahlawan tanpa tanpa tanda jasa yang kehadirannya selalu digandrungi dan diharap-harapkan oleh mereka para pecinta ilmu yang begitu haus akan ilmu baru. Oleh karena itu, Desi ingin menjadi seorang guru dan mengabdikan hidupnya demi mencerdaskan kehidupan bangsa.

Dalam kutipan tersebut membuktikan bahwa tema dalam novel Guru Aini adalah pendidikan dan idealisme seorang guru demi mewujudkan impiannya untuk mencerdaskan bangsa.

b. Tema Minor

Selain mempunyai tema utama atau tema mayor, novel Guru Aini mempunyai tema minor atau tema tambahan. Tema minor yang terdapat dalam novel Guru Aini adalah tema mengenai persahabatan.

“Sore itu pula Aini, Enun, dan Sa'diah berlomba-lomba mengayuh sepeda ke pasar untuk minim-minum merayakan kemungkinan Aini bisa pindah ke kelas Bu Desi. Sentosa benar mereka bisa minum es tebu di warung gerobak Bang Tebudin.” (Guru Aini, hal. 102)

Dalam kutipan tersebut, membuktikan bahwa novel Guru Aini mengandung tema mengenai persahabatan. Aini, Enun, dan Sa'diah merupakan sahabat karib yang bukan hanya dekat di sekolah saja, melainkan juga di rumah mereka menjadi teman bermain. Dalam segala hal mereka lalui bersama, bahkan mengulang di kelas pun mereka sepakati bersama.

2. Alur 
Berdasarkan hasil penelitian yang telah dilakukan oleh peneliti, alur yang digunakan dalam cerita ini, adalah alur maju mundur dengan pembuktian disetiap jalannya cerita mengisahkan masa depan juga mengungkit masa lalu.

Alur yang digunakan pengarang dalam novel Guru Aini adalah dengan menggunakan alur campuran atau alur maju-mundur dengan tahapan sebagai berikut:

a. Tahap awal

"Sejak berjumpa dengan Bu Marlis, kelas 3 dulu, aku sudah ingin menjadi guru matematika, Bu." (Guru Aini, hal. 1)

Dalam kutipan novel tersebut, menjelaskan bahwa awal dari sebuah kisah mengenai perjuangan seorang guru bernama Desi Istiqomah adalah karena sosok yang menjadi panutan baginya yakni Bu Marlis. Desi sangat menjadikan Gurunya yang bernama Ibu Marlis sebagai sosok yang memberi teladan bagi hidupnya. Desi ingin menjadi seorang guru matematika yang mempunyai idealisme tinggi serta dedikasi yang dapat mencetak generasi bangsa yang jenius akan matematika.

b. Tahap tengah

"Selama mengajar tak pernah aku bertemu murid secerdasmu, But! Tak pernah ! Tak tahu aku apa yang ada dalam pikiranmu." (Guru Aini, hal. 64 )

Dalam kutipan tersebut, memunculkan tahap dari sebuah konflik dimulai. Guru Desi begitu kecewa dengan keputusan murid tercerdasnya yang kali pertama dia jumpai selama bertahun-tahun mengajar. Guru Desi begitu sakit hati kepada sosok Debut Awaludin yang meninggalkan matematika, kelas, bahkan sekolahnya demi segerombol murid yang disebut dengan rombongan 9. Debut Awaludin terbawa arus negatif teman-temannya sehingga dia sering bolos sekolah, malas mengerjakan matematika bahkan ikut serta putus sekolah dikarenakan pergaulannya terhadap rombongan 9 .

c. Tahap akhir

"Dengarlah baik-baik, kita sudah berjumpa selama 5 minggu. Minggu pertama, aku menguji sekuat apa mentalmu untuk belajar matematika. Ternyata 
mentalmu cukup kuat. Minggu kedua, aku kecewa, karena susah sekali mengajarimu. Minggu ketiga aku jengkel, karena kau tak mengerti apapun yang kuajari. Minggu keempat, aku marah, karena kau semakin bingung. Minggu kelima, aku muntab ! Karena kau sama sekali taka da kemajuan, sehingga ku robek-robek kertas jawabanmu itu. Dapatkah kau melihat, aku semakin marah karena..." (Guru Aini, hal. 188)

Dalam kutipan tersebut, menjelaskan bahwa Guru Desi menemukan cara khusus untuk mengatasi kesulitan belajar matematika pada Aini. Guru Desi menggunakan materi kalkulus sebagai penyelesaiannya. Dijadikannya permasalahan pada soal-soal matematika secara nyata sehingga dengan mudah Aini dapat menyerapnya, meski membutuhkan waktu cukup lama untuk memahamkan Aini.

\section{Tokoh dan Penokohan}

Penokohan dalam novel ini, menggunakan tokoh utama dan tokoh tambahan. Adapun pelaku yang dijadikan tokoh utama adalah Desi Istiqomah sebagai guru matematika yang mempunyai pendirian teguh, dermawan serta tangguh dalam menghadapi siswa-siswinya. Hal tersebut dibuktikan dengan kutipan sebagai berikut;

"Itulah harapan terbesar dalam hatiku, karena aku selalu merasa, menjadi guru matematika adalah alasan mengapa di dunia ini, aku, Desi Istiqomah, ada.” (Guru Aini, hal. 1)

"Dia tak bisa melihat murid-muridnya tak punya buku. Selalu dibelikannya murid-muridnya yang tak mampu itu buku-buku tulis, buku-buku teks, dan sepatu. Nur kecil kesekolah sambil memeluk buku-bukunya karena tak punya tas. Tak ragu Guru Desi mengeluarkan buku-bukunya dalam tasnya sendiri lalu memberikan tas yang agak besar itu pada Nur. Nur juga suka telat ke sekolah kareana sepeda bututnya suka lepas rantainya. Sorenya Guru Desi ke toko sepeda, esoknya Nur naik sepeda keranjang baru sambil menyandang tas sekolah yang besar." (Guru Aini, hal. 134)

"Ingat benar Ibu saat kejadian Desi jatuh dari sepeda itu. Bersimbah darah wajahnya. Ibunya mau pingsan. Si kecil yang baru berusia 8 tahun itu menangis 
saja tidak. Dilarang keras dia main sepeda, esoknya dia main sepeda lagi. Belum sembuh luka di atas alis itu, dia jatuh dari pohon jambu, patah tangannya, dia juga tidak menangis." (Guru Aini, hal. 6)

Adapun Nuraini sebagai murid tertinggal dengan mata pelajaran matematika namun mempunyai tekad kuat dalam menggapai impiannya.

"Mungkin kau satu-satunya anak di dunia ini yang mau belajar matematika karena ingin mengobati sakit seorang ayah.” (Guru Aini, hal 100)

Sedangkan tokoh tambahan adalah Debut Awaludin, Pak Tabah dan Laila. 4. Latar

Latar yang digunakan adalah dengan menggunakan latar tempat berupa rumah, perpustakaan, jalan, pasar, kelas, dermaga, terminal, warung makan, ruang kepala sekolah dan sekolah. Latar waktu dengan menunjukkan sore hari, tempo hari, seminggu, senin, hari mendatang, 18 tahun serta 5 hari yang lalu. Sedangkan latar sosial ditunjukkan dengan panggilan kehormatan, rasa kedermawanan, idealisme serta kemiskinan.

Berikut merupakan kutipan latar dalam novel Guru Aini;

1. Latar tempat

"Pembicaraan itu terjadi dalam sebuah rumah di satu kota kecil di tengah Pulau Sumatera sana." (Guru Aini, hal. 2)

"Sttt! Seseorang di sebelah situ memperingatkan sebab pertengkaran itu terjadi di perpustakaan Runding memang sudah kuliah di USU.” (Guru Aini, hal. 3)

2. Latar waktu

"Sudah terlalu jauh untuk dikejarnya. Apalagi Desi melangkah cepat-cepat sebab sore ini dia harus bertemu dengan ibunya dan Kepala SMA-nya yang mau bicara dengannya." (Guru Aini, hal 4) 
"Sejak 5 hari yang lalu, Desi sudah naik bus besar, naik bus mini, naik angkutan umum kecil, naik ojek, naik kapal besi, naik kapal kayu, dari terminal ke terminal, dari dermaga ke dermaga, kini dia naik angkutan umum kecil lagi." (Guru Aini, hal 23)

3. Latar sosial

"Dihitung dari anak buah kapal senior tadi, sejak menginjakkan kaki di pelabuhan, sudah 2 orang memanggilnya Nong. Segera Desi mengerti, mungkin begitu cara orang Tanjong Hampar memanggil perempuan. Dan dari cara mengatakannya, tampaknya Nong adalah panggilan penuh hormat dan sayang." (Guru Aini, hal. 29)

"Seharusnya anak yang cerdas tak lahir dari keluarga morat-marit seperti ini, dan tak punya cita-cita yang tinggi, karena hal itu nanti hanya akan menghancurkan hati anak itu sendiri. Hari ini Dinah menyesali hidupnya sebagai orang miskin.” (Guru Aini, hal. 213)

4. Sudut Pandang

Sudut pandang yang digunakan dalam novel Guru Aini menggunakan sudut pandang persona ketiga dengan teknik "dia” mahatahu. Dalam hal ini, penulis seolah-olah menyaksikan langsung peristiwa yang dialami serta mengetahui segala hal yang terjadi pada tokoh Desi dan Aini, sehingga menulisnya agar pembaca dapat mengerti apa yang telah terjadi pada tokoh-tokoh yang terdapat dalam sebuah cerita.

Adapun bukti bahwa novel Guru Aini menggunakan sudut pandang perdona ketiga dengan teknik "dia" mahatahu adalah sebagai berikut:

"Bu Desi. Kata Desi pelan pada setiap murid yang menghampirinya. Desi semakin berdebar-debar. Dia telah memiliki sertifak sebangai pengajar matematika, dia sudah punya SK pengangkatan dari negara sebagai guru dan pegawai negeri sipil. Namun, baru pagi itu, ketika murid-muridnya menyalami dan mencium tangannya, dia baru merasa benar-benar menjadi seorang guru." (Guru Aini,hal. 36)

Dalam kutipan tersebut, narator menceritakan tokoh utama yakni Desi Istiqomah dengan menyebutnya "dia". Hal tersebut membuktikan bahwa teknik yang digunakan dalam novel kajian penelitian ini adalah dengan menggunakan 
sudut pandang persona ketiga dengan teknik "dia".

Penulis seolah-olah ikut menyaksikan jalan cerita serta mengetahui perasaan yang dialami oleh tokoh. Narator seolah-olah menyaksikan langsung peristiwa tersebut dan menulisnya agar pembaca dapat mengerti apa yang telah terjadi pada tokoh-tokoh yang terdapat dalam sebuah cerita.

5. Amanat

Amanat yang yang terkandung dalam novel tersebut berupa, seorang guru yang harus mempunyai idealisme tinggi demi memcerdaskan kehidupan bangsa, sikap pantang menyerah dan selalu berbakti kepada orang tua dalam keadaan apapun.

Dalam novel ini, terdapat 4 nilai moral yang berupa; 1). nilai hubungan manusia dengan Tuhan yakni memanjatkan doa, bersyukur kepada Tuhan, berserah diri kepada Tuhan, dan mengakui keslahan dihadapan Tuhan. 2). Hubungan manusia dengan diri sendiri yakni Memaafkan Diri Sendiri, percaya diri, berjanji, sadar diri pantang menyerah, mengakui kesalahan, menerima kenyataan. 3). Hubungan manusia denga sesama yakni peduli, rela berkorban, bertanggung jawab, berbagi dan memberi, ,menghormati dan menghargai, jujur, tidak memaksakan kehendak, berbakti kepada orang tua, tolong menlong, berprasangka baik, menepati janji. dan berterimakasih. 4). Hubungan manusia dengan lingkungan yakni mematuhi peraturan,

Adapun nilai sosial yang terkandung berupa 1). kasih sayang Zubaiedi, 2005: 13 (dalam Skripsi Umi Khomsiyatun, 2016) membagi kasih sayang membagi empat bagian yakni : pengabdian, tolong menolong, kesetiaan, kepedulian. 2). tanggung jawab (Zubaedi, 2005: 13) terdapat tiga hal yang berhubungan dengan tanggung jawab yakni, Nilai Rasa Memiliki, disiplin, dan empati. 3). keserasian hidup Menurut Zubaedi, keserasian hidup dibagi menjadi empat macam, yakni : keadilan, toleransi, kerjasama, dan demokrasi.

\section{E. Simpulan}


Berdasarkan penelitian yang telah dilakukan, maka dapat ditarik simpulan. Berikut simpulan hasil penelitian atas kajian struktural, nilai moral dan nilai sosial pada novel Guru Aini karya Andrea Hirata.

1. Struktur novel Guru Aini karya Andrea Hirata dapat dideskripsikan sebagai berikut.

a. Tema dalam novel Guru Aini karya Andrea Hirata adalah tentang pendidikan dan perjuangan dalam menggapai impian.

b. Penokohan dalam novel Guru Aini menggunakan penokohan sesuai dengan kadar dan tingkatan keutamaan yang dikategorikan menjadi dua macam yakni tokoh utama dan tokoh tambahan. Tokoh-tokoh yang dimunculkan dalam novel Guru Aini, dimunculkan oleh pengarang dengan melukiskan secara eksplisit dari kondisi fisik maupun kondisi psikisnya pada masing-masing tokoh.

c. Latar yang digunakan dalam novel Guru Aini, menggunakan latar tempat yakni berupa tempat di rumah, perpustakaan, jalan, pasar, kelas terminal bus dermaga, warung makan, sekolah, ruang kepala sekolah. Adapun latar waktu menunjukkan sore, hari mendatang, 5 hari yang lalu, 18 tahun, tempo hari, seminggu, senin. Sedangkan latar sosial menyatakan panggilan kehormatan, dermawan, idealisme, dan juga kemiskinan.

d. Alur yang digunakan dalam novel Guru Aini karya Andrea Hirata adalah alur campuran (regresif dan progresif). Dalam alur yang dikisahkan dalam cerita tersebut, terdapat beberapa alur mundur yang mengenang masa lalu serta menceritakan kisah yang pernah dialami oleh tokoh pada masa lalu.

e. Sudut pandang yang digunakan dalam novel Guru Aini adalah dengan menggunakan sudut pandang persona ketiga dengan teknik "dia" yang berperan sebagai mahatahu.

f. Amanat yang terkandung dalam Guru Aini, berupa pesan idealisme seorang guru, sikap pantang menyerah dan berbakti kepada kedua orang tua.

2. Nilai Moral dalam Novel Guru Aini

Nilai moral yang terkandung dalam novel Guru Aini meliputi nilai mengenai hubungan manusia dengan Tuhan, hubungan manusia dengan diri 
sendiri, hubungan manusia dengan sesama dan hubungan manusia dengan lingkungan.

3. Nilai Sosial dalam Novel Guru Aini

Nilai sosial yang terkandung dalam novel Guru Aini meliputi nilai kasih sayang, tanggung jawab dan keserasian hidup.

\section{E. Daftar Pustaka}

Hirata, Andrea. 2020. Guru Aini. Yogyakarta: Bentang Pustaka.

kbbi.kemdikbud.go.id/er

Khomsiyatun, Umi. 2016. Skripsi. Nilai Sosial Masyarakat Pedesaan Dalam Novel Tenun. Purwokerto: Universitas Muhammadiyah.

Moleong J. Lexy. 2013. Metodologi Penelitian Kualitatif (edisi revisi). Bandung: PT. Remaja Rosdakarya.

Nurgiyantoro, Burhan. 2010. Teori Pengkajian Fiksi. Yogyakarta: Gajah Mada. University Press.

Nurgiyantoro, Burhan. 2018. Teori Pengkajian Fiksi. Yogyakarta: Gajah Mada. University Press.

Rafiek, M. 2013. Pengkajian Sastra: Kajian Praktik. Bandung: Rafika Aditama. Sugiyono.2017. Metode Penelitian Kuantitatif, Kualitatif, Dan R\&D. Bandung: Alfabeta,CV. 